\title{
As rendeiras e a cerzideira ou a metafísica do instante
}

\author{
Lúcia Peixoto Cherem
}

O romance $A$ hora da estrela* foi lançado no Brasil em 1977, ano da morte de sua autora. Clarice Lispector tem reservas quanto a sua última obra, acha-a artificial e simplificadora. Rocco, 1998.) Ao menos é o que deixa transparecer na dedicatória do exemplar oferecido à sua amiga e secretária Olga Borelli: "Olga, este livro não é bom, é superficial, mas que é que se há de fazer? A inspiração vinha. Mas a preguiça e o desânimo também. Você é que fustigou minha preguiça e desânimo. Sem você o livro não sairia, você bem sabe disso. Eu não digo 'obrigada' porque é pouco. Receba-o com um abraço amigo".

Podemos nos perguntar sobre o lado superficial que Clarice aponta em seu próprio livro. Talvez essa característica da obra, que desagrada a Clarice, esteja relacionada a uma estrutura clara, a um narrador masculino que a impede de resvalar, a personagens bem delineados. Macabéa, no entanto, parece ser o contraponto para essa superficialidade, pois desarruma tudo com seu jeito torto de ser e de viver. Desnorteando a todos, até ela própria, que do Nordeste desceu ao Rio de Janeiro para se perder na cidade grande.

Um outro romance, $A$ rendeira, de Pascal Laîné, também apresenta uma moça simples, chamada Pomme. A personagem trabalha num salão de beleza, tem uma vida comum, mas nela há algo de inquietante, que não pode ser explicado nem revelado, segundo o narrador da história. É também um homem que conta, e o livro tem versão para o cinema, assim como $A$ hora da estrela. ${ }^{1}$

A obra de Pascal Laîné ganhou o prêmio Goncourt de melhor romance em 1974. Até aí a aproximação dos dois poderia ser um simples exercício comparativo, se não houvesse um fato curioso ligando-os: em 1975, o livro é traduzi-

${ }^{1}$ Os filmes: A Hora da Estrela, de Suzana Amaral (1986), e La Dentellière, de Claude Goretta e Pascal Laîné (1976). Marcela Cartaxo ganha o prêmio de melhor atriz por sua atuação como Macabéa no Festival de Cinema de Berlim em 1986. 
"(Ribeiro, Leo Gilson. "A hora das estrelas". Jornal da Tar. de, São Paulo, 19 de novem bro de 1977: 19.)

"(Lispector, Clarice. A pa. xão segundo G.H. Rio de Ja neiro: Rocco, 1998.)

" (Lispector, Clarice. Água viva. Rio de Janeiro: Rocco, 1998.) do para o português e lançado no Brasil pela editora Imago. Tradutora: Clarice Lispector.

Além de Pomme e Macabéa apresentarem características comuns, a estrutura dos dois romances é quase a mesma. Pomme e Macabéa vivem desajustadas, estão despreparadas para o mundo que as cerca. Diríamos que Macabéa ainda mais, pela dura realidade a que é exposta na vida social brasileira: órfã de pai e mãe, é criada por uma tia no Nordeste, no Estado de Alagoas. Pomme também tem uma infância difícil: é filha de uma mulher pobre, abandonada pelo marido, e que, além de garçonete em um bar, prostituía-se aos clientes para segurar o emprego.

Duas vidas ralas paralelas nos levam a pensar no arcabouço usado por Clarice em seu último romance. Quando o livro é lançado no Brasil, a crítica o elogia e afirma que Clarice está menos hermética. Além disso, teria enveredado, pela primeira vez, pelo caminho da "coisa” social. Mas houve críticos mais lúcidos que reagiram a esse simplismo:

Agora com este livro publicado, "A Hora da Estrela", seria ridículo afirmar que Clarice Lispector sucumbiu às pressões para que escrevesse um livro "em defesa dos oprimidos" ou que ela aceitasse o desafio absurdo de "provar" que é capaz de escrever sobre os seres que só existem nas estatísticas populacionais, como o naturalista Zola "provou” ser capaz de criar voluntariamente uma obra romântica. Não. A raiz oculta de "A Hora da Estrela” está em qualquer de seus contos ou romances mas mais evidentemente em "Amor" $[\ldots]^{*}$.

Podemos nos perguntar por que Clarice apresentava agora uma estrutura narrativa mais acabada, depois de ter trabalhado arduamente com textos despojados de construções mais tradicionais, como A paixão segundo G.H.* ou o inquietante Água viva*. Nestes dois últimos textos, ela foi capaz de revelar o seu próprio fazer literário, sua maneira difícil de trabalhar, apresentando ao leitor o presente da escrita, seus instantes. Não seria essa uma das razões de ter escrito a Olga Borelli que seu romance era superficial? Ou seria ainda por ter tentado em vão captar Macabéa pela escrita? Captou-a sim na rua, pois teria apreendido a vida de uma moça num sábado em São Cristóvão. Como explicar a limpidez estrutural de $A$ hora da estrela? 
Traduzir uma obra é também, de certa forma, um exercício de escrita, e Clarice Lispector não é indiferente, a meu ver, à trama de $A$ rendeira. Pomme, a heroína do romance, conhece um rapaz que se torna seu namorado durante a narrativa. Aimery não a entende, embora perceba nela uma sensibilidade incomum. Trata-se de um estudante de Letras em Paris. Muito mais sensível que o nosso Olímpico de Jesus, namorado de Macabéa, ou que Rodrigo S. M., o narrador masculino do romance brasileiro? Não necessariamente. $\mathrm{O}$ preparo intelectual de Aimery não lhe permite enxergar Pomme: há algo nela que não consegue captar e que, se o fascina, também o irrita profundamente:

$\mathrm{O}$ rosto de Pomme mostrava alguma coisa de claro e transparente. Entretanto, o que se decifrava era ingênuo e decepcionante. Tratava-se, porém, de ler? O estudante deliciava-se com o pensamento de que havia nesse rosto uma mensagem provisoriamente indecifrável. Ora, a substância de que Pomme era feita, tão preciosa, pode-se adivinhar, revelava-se através de uma opacidade sem defeitos, como uma jóia cuja perfeição fosse não ter brilho. E todos os esforços de Aimery para apoderar-se de Pomme, depositar nela cores e reflexos, segundo o que queria acreditar dela, fracassavam da mesma maneira.*
Le visage de Pomme avait quelque chose de net et de lisible. Pourtant on ne pouvait rien déchiffrer que de très naïf et de décevant. Mais s'agissait-il de lire? L'étudiant se plaisait à la pensée qu'il devait y avoir là comme un message, provisoirement indéchiffrable. Or la substance dont Pomme était faite, aussi précieuse la devinât-on, se révélait d'une opacité sans défaut, comme un bijou dont la perfection eût été de n'avoir point d'éclat. Et les efforts d' Aimery pour se saisir de Pomme, pour y déposer des couleurs, des reflets selon ce qu'il voulait croire d'elle, échouaient tous de la même manière.*
"(Laîné, Pascal. A rendeira. Tradução de Clarice Lispec. tor. Rio de Janeiro: Imago, 1975: 73.)

- (Laîné, Pascal. La dentel. lière. Paris: Gallimard, 1974: 103.)

O narrador Rodrigo S. M. e Olímpico, de $A$ hora da estrela, têm essa mesma sensação em relação a Macabéa:

Ela me incomoda tanto que fiquei oco. Estou oco dessa moça. E ela tanto mais me incomoda quanto menos reclama. Estou com raiva. Uma cólera de derrubar copos e pratos e quebrar vidraças. Como me vingar? Ou melhor, como me compensar? Já sei: amando meu cão que tem mais comida do que a moça. Por que ela não reage? Cadê um pouco de fibra? Não, ela é doce e obediente*. 
Depois da chuva do Jardim Zoológico, Olímpico não foi mais o mesmo: desembestara. E sem notar que ele próprio era de poucas palavras como convém a um homem sério, disse-lhe:

- Mas puxa vida! Você não abre o bico e nem tem assunto!*

Pomme tem uma amiga chamada Marylène, mas elas são muito diferentes: Marylène é cabelereira, enquanto Pomme é somente uma ajudante no mesmo salão de beleza. E a ligação delas é tênue demais para suportar uma curta viagem de férias ao litoral norte francês, onde Pomme, abandonada por Marylène, acaba encontrando Aimery, seu futuro namorado. Glória é quem sabe das coisas em $A$ hora da estrela: tem um corpo apetitoso, alimenta-se bem, domina o ambiente de trabalho e rouba o namorado de Macabéa. Porém a semelhança entre as estruturas dos dois romances não é o que nos interessa aqui: o fato de Clarice Lispector ter talvez se baseado no romance francês para estruturar sua obra é algo sem importância alguma, se considerarmos o resultado que consegue ao investigar sua Macabéa.

A aproximação dos dois romances só encontra justificativa como trabalho de reflexão no momento em que se tenta ver o que há de comum entre Macabéa e Pomme. Quem são essas personagens e o que elas representam na literatura?

O filme $A$ rendeira traz imagens que revelam melhor com que intenção o título foi dado ao livro: Isabelle Huppert, interpretando Pomme, aparece em várias cenas cotidianas também descritas no romance: o corpo e a tarefa estão indissociavelmente ligados. Segue trecho do texto em que Pomme é descrita durante uma de suas tarefas:

Suas mãos breves tornavam-se febris quando ela se punha a tricotar: era algo que quase se separava dela mas sem romper nela a unidade da leveza e de certa massividade. Seu trabalho, não importa qual, tornava-se imediatamente esse acordo, essa unidade. Ela era sempre o tema de um desses quadros onde a composição, o assunto, suscitam seu modelo como preso em seu gesto. Seu modo, por exemplo, de prender entre os lábios os
Ses mains brèves devenaient fébriles quand elle s'exerçait à tricoter: ça se détachait presque d'elle, mais sans rompre en elle l'unité de la finesse et d'une certaine massivité. Sa tâche, n’importe laquelle, devenait immédiatement cet accord, cette unité. Elle était cette fois-là comme les autres le sujet d'un de ces tableaux de genre où la composition, l'anedocte suscitent leur modèle comme enchâssé dans son geste. Cette manière qu'elle avait, par exemple, de pin- 
grampos do cabelo quando refazia seu coque! Ela era Lavadeira, Carregadora de Água, ou Rendeira.* cer entre ses lèvres les épingles à cheveux quand elle refaisait son chignon! Elle était Lingère, Porteuse d'eau ou Dentellière."
•(Laîné, Pascal. A rendeira. Ob. cit.: 13.)

"(Laîné, Pascal. Ob. cit.: 16.7.)

Há, no trecho acima, a referência explícita ao quadro de Vermeer que leva o mesmo título do romance: $A$ rendeira.

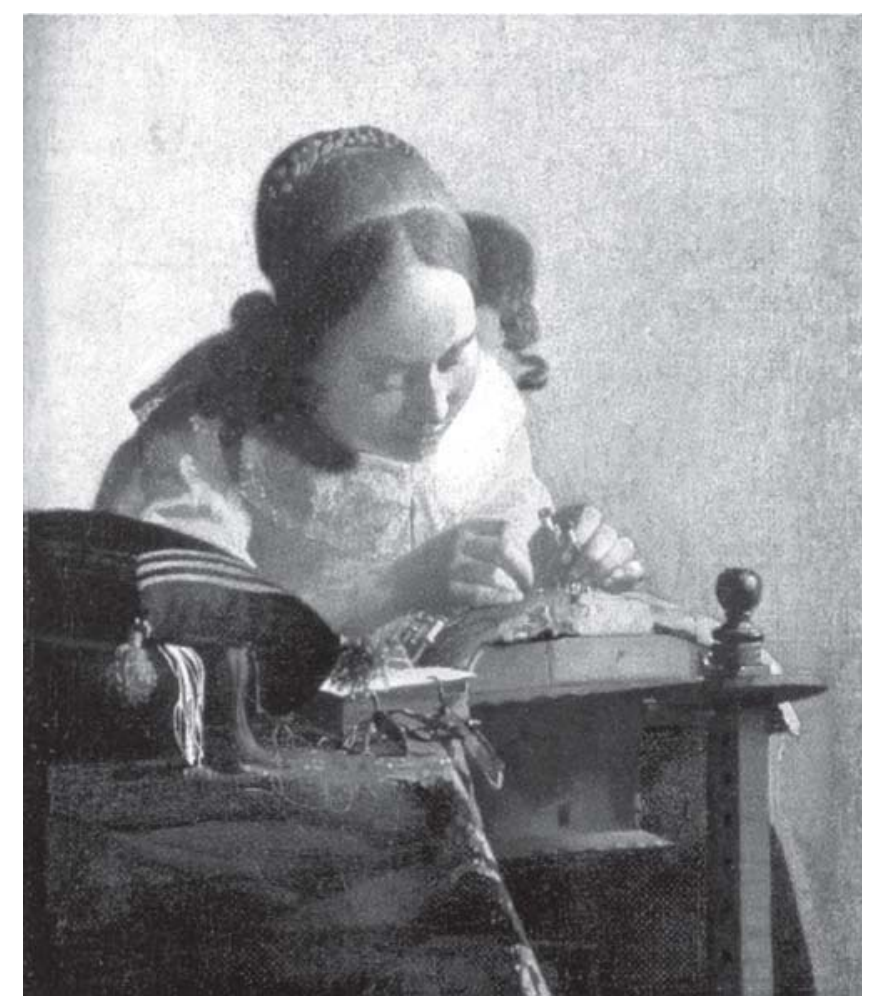

A Rendeira [Vermeer, 1664]- Museu Starliche, Berlim óleo sobre tela, $42,5 \times 32 \mathrm{~cm}$

Na Holanda do século XVII, um pintor olhou com atenção o trabalho doméstico de muitas mulheres no interior das casas: $A$ rendeira é um desses quadros em que, concentrada, com o olhar atento, a mulher trabalha. Os afazeres da costura e do bordado eram considerados desde o fim da Idade 
Média como uma tarefa conveniente às mulheres, em que eram necessárias modéstia, paciência e perseverança, valores impostos a elas na reclusão da casa.

Vermeer foi sensível ao universo feminino, porque suas figuras não estão somente a serviço dos valores da época que limitavam a mulher a uma determinada experiência de vida, como tantos outros pintores contemporâneos seus foram capazes de mostrar. Nas mulheres de Vermeer, há momentos em que a tarefa é feita pela mão, pelo braço, mas o pensamento está em outro lugar. A mulher pode estar refletindo, lembrando-se ou simplesmente sendo. Está imersa na tarefa, no setor social que lhe coube, o interior da casa. Presente no trabalho mas ao mesmo tempo alheia. No intervalo entre uma tarefa e outra, haveria a ousadia de uma possível metafísica do instante? Há, às vezes, uma suspensão do fazer que deixa aflorar um modo de ser.

Essa pintura, expressão artística talvez com menos barreiras que a literatura, soube mostrar, antes das letras, uma vida interior que não encontrava ainda expressão em palavras. O silêncio da pintura é repleto: essas imagens falam de uma apreensão do dia-a-dia, de um pensar fragmentado entre tarefas; de ordem e desordem, de fazer e não fazer.

Foi nesse espaço limitado que muitas mulheres desenvolveram sua forma de refletir sobre o mundo. Os quadros de Vermeer, portanto, evocam um segredo que se guarda, um modo de compreender a vida que vem do corpo recluso na casa, que vem de um bem-estar de ter e ser este corpo. Esse "largar-se" no intervalo de duas tarefas domésticas vem acompanhado de um "cismar", um estar à toa que pode parecer sonso. É desse estar "sonso" no mundo que procurarei falar a respeito dos dois romances em questão: $A$ hora $d a$ estrela e $A$ rendeira. ${ }^{2}$

${ }^{2}$ Esse "gozo do ser" é muito bem descrito por Malvine Zalcberg, em seu livro $A$ relação mãe e filha, no qual explica como ocorre a castração: "A castração, cuja significação é a inscrição do sujeito na linguagem, determina que homens e mulheres devem perder um certo gozo que o próprio corpo pode lhes proporcionar: esse gozo, ilimitado, seria o gozo do ser. Por ser ilimitado, 'gozo do idiota', como o chama Lacan, ele é vedado a quem fala, pela lei da castração” (Rio de Janeiro: Campus, 2003: 121). 


\section{Vermeer, o mundo íntimo e a literatura}

Annie Leclerc, em seu texto Lettre d'amour', refere-se ao outro quadro de Vermeer aqui representado: Senhora escrevendo uma carta e criada. A ensaísta fala sobre duas mulheres: a patroa escrevendo provavelmente uma carta de amor, gênero considerado "feminino" por excelência (a sociedade permite à mulher escrever sobre os sentimentos), e a doméstica conivente, esperando a senhora acabar a carta para levá-la ao destinatário, talvez um amante. O quadro certamente denuncia uma prática da época, mas revela ao mesmo tempo os limites de um mundo em que somente alguns movimentos eram possíveis. Annie Leclerc, nesse texto, escreve uma carta à sua mãe em que diz:

Vem, eu queria tanto te contar o segredo que guardo da senhora que escreve, que lhe vem de sua criada, que o capta do segredo em que mulheres nós somos $[\ldots]$

Mulher criada, mulher do obscuro labor sem salário, mulher de silêncio realiza, mas que sabe ver, tocar, ouvir, é ela quem me engendra. Sim, é apenas desse corpo que provenho, apenas dele me vêm a potência e o apelo ardente do querer-dizer. Assim, às vezes, olhava minha mãe, que olhava ao longe, e eu tinha sede desse olhar habitado pelas coisas, e tinha sede das coisas presentes nesse olhar.

Olhar em outra direção, esse olhar perdido e prenhe de segredos. Vermeer não é indiferente a esse modo de ver e ser que não se expressa. $\mathrm{O}$ narrador de $A$ rendeira tem a mesma apreensão de Pomme: ele a olha viver, ser física e espiritualmente no mundo, mas não consegue ir mais longe. Não há comunicação possível porque Pomme revela por meio de seu corpo o que cala: não sabe expressar o que sente ou o que deseja. Essa incapacidade irrita o narrador, que parece poder, assim, justificar o abandono da moça pelo namorado. No

${ }^{3}$ Trata-se de um conjunto de ensaios sobre escrita feminina. Os outros dois textos são de Hélène Cixous e de Madeleine Gagnon, e foram publicados um pouco antes de a obra de Clarice Lispector ser retraduzida na França pela editora Des Femmes (Lettre d'amour. La venue à l'écriture. Série Féminin Futur, Col. 1018, UGE, 1977). 
início da relação, ele a mitifica, considera-a enigmática, mas depois se decepciona com seu silêncio:

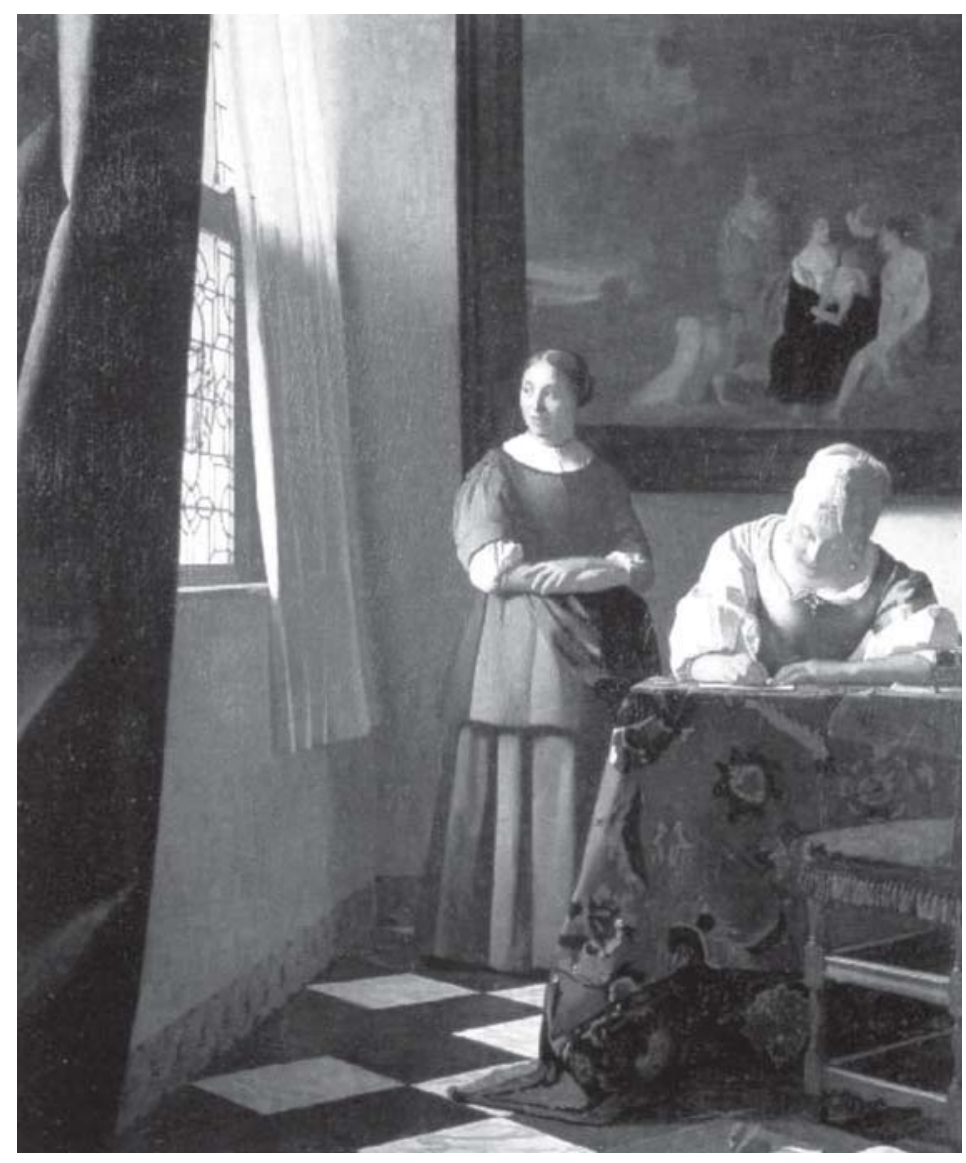

Senhora escrevendo uma carta e criada $\left[\right.$ Vermeer, $\left.1670^{`}\right\rceil$ National Gallery of Ireland, Dublin óleo sobre tela, $71 \times 59 \mathrm{~cm}$

Brigava com Pomme por não exigir nada dele e não dar assim nenhum valor ao que ele queria darlhe. Parecia que ela não desejava tomar nada. Podia mostrar-se desagradável, recusar falar-lhe durante uma noite inteira, e era sempre ele que acabava cedendo, tocado por sua própria dureza, sem que Pomme fizesse qual-
Il reprochait à Pomme de ne rien exiger de lui, et de n'accorder ainsi nulle valeur à ce qu'il voulait lui donner. Mais il semblait qu'elle ne désirât rien prendre. Il pouvait se montrer désagréable, refuser de lui parler pendant toute une soirée, c'était toujours lui qui finissait par céder, ému de sa propre dureté, sans que Pomme se fût 
quer queixa ou pedisse alguma coisa: então era a dureza de Pomme que o confundia. Acendia um Gitane com filtro.

Agora, evitava passar com ela longos momentos de lazer, por causa desses silêncios, dela, dele, e dela ainda. De noite, depois de uma refeição leve, ele simplesmente retomava as leituras da tarde, em livros apanhados na biblioteca. Pomme lavava a louça, bem devagar; como se tivesse medo de ficar inativa na sua frente. E quando terminava a louça, ou então de lavar roupa, folheava com toda a atenção livros da Gallimard que ele dissera para ela ler. Seus dedos cheiravam a detergente de limão. plainte et lui eût rien demandé; alors c'est la dureté de Pomme qui le confondait. Il allumait une Gitane-filtre.

Maintenant il évitait de passer avec elle de longs moments d'oisiveté, à cause de ces silences, d'elle, de lui, et d'elle encore. Le soir, après leur bref repas, il reprenait simplement ses lectures de l'aprèsmidi, dans des livres empruntés à la bibliothèque. Pomme s'affairait à la vaisselle, très longuement; comme si elle avait eu peur de rester inactive devant lui. Et quand elle avait fini avec la vaisselle, ou bien avec le linge, elle feuilletait attentivement des livres de chez Gallimard qu'il lui avait dit de lire. Ses doigts sentaient bon le Paic-Citron.*
-(Laîné, Pascal. A rendeira. Ob. cit.: 88-9.)

• (Laîné, Pascal. La dentellière. Ob. cit.: 127.8.)

O que acontece com Macabéa? A personagem também é descrita por um narrador masculino, Rodrigo S. M., no entanto é cria de uma mulher. Em verdade, Clarice Lispector esclarece no início da obra ser ela a verdadeira autora do romance. Talvez tenha escolhido um narrador masculino para poder se distanciar de Macabéa, de sua própria experiência de escritora e mulher no mundo. Incorpora o ponto de vista masculino para realizar sua obra de cunho social. Mera coincidência? Parece que não. Nesse seu último romance, poderíamos dizer que há um acerto de contas: falará sim sobre Macabéa, sua alma gêmea. E fará um romance que denunciará uma realidade. Falar da "coisa social" sempre foi difícil para ela. Mas como brasileira e nordestina que era, acabou demonstrando que sabia fazêlo, mesmo que o resultado the parecesse superficial. Clarice sabia que a literatura não mudaria a vida das macabéas e dos olímpicos; sabia também que quem a lia estava bem alimentado. Não se conformava com a pobreza que conhecera em sua infância no Recife e tampouco acreditava nessa escrita engajada que só serviria para resolver um problema de consciência do autor. Apesar dessa sua visão madura, foi muito criticada por não ter tratado do problema social brasileiro anteriormente. 
"(Lispector, Clarice. A hora da estrela. Ob. cit.: 26.)
"(Laîné, Pascal. A rendeira. Ob. cit.: 19) ["Elles sont de ces arbustes qui trouvent toute leur terre dans la fis. sure d'un mur, dans l'inters. tice entre deux pavés; et c'est de leur végétalité qu' elles tiennent une vigueu paradoxale"]. (Laîné Pasca. La dentellière. Ob. cit.: 26.)

"(Lispector, Clarice. A hor da estrela. Ob. cit.: 60.)
A diferença em $A$ hora da estrela é que Clarice faz falar Macabéa, mesmo que ela tenha menos recursos que Pomme. Não chega a ser uma rendeira daquelas de mão cheia como há no Nordeste. Macabéa é apenas uma cerzideira:

A moça tinha ombros curvos como os de uma cerzideira. Aprendera em pequena a cerzir. Ela se realizaria muito mais se desse ao delicado labor de restaurar fios, quem sabe se de seda. Ou de luxo: cetim bem brilhoso, um beijo de almas. Cerzideirazinha mosquito. Carregar em costas de formiga um grão de açúcar. Ela era de leve como uma idiota, só que não o era. Não sabia que era infeliz. É porque ela acreditava. Em quê? Em vós, mas não é preciso acreditar em alguém ou em alguma coisa - basta acreditar. Isso lhe dava às vezes um estado de graça. Nunca perdera a fé.*

O que acontece nessa literatura do século XX? Até mesmo a aparentemente "sonsa" Macabéa tenta quebrar o silêncio, tenta entrever, mesmo que confusamente e com armas muito precárias, seu lugar no mundo.

Clarice Lispector quer fazer falar Macabéa, que, no entanto, não sabe falar. Mas há na personagem uma curiosidade sobre as palavras da língua: algumas chamam sua atenção, como efemérides, que acha esquisita sem saber o significado. Ouve a rádio-relógio para aprender coisas sobre o mundo, tem alegrias íntimas, como no dia em que mente que precisa ir ao dentista para não ir trabalhar e ficar consigo mesma. Passa o dia no quarto da pensão, um pequeno luxo dentro da sua miséria. Macabéa não tinha floração, era capim. Essa descrição da personagem coincide mais uma vez com aquela de Pomme e de sua mãe, feita por Pascal Laîné no romance $A$ rendeira: "Elas são dessa espécie de heras que encontram toda a sua terra na rachadura de um muro, entre dois paralelepípedos; e é da sua vegetalidade que elas tiram um vigor paradoxal"*.

Macabéa e Pomme são abandonadas pelos respectivos namorados. Aimery não suporta mais o peso do seu silêncio durante as tarefas da casa e o fato de a moça ficar sem fazer nada a seu lado. José Olímpico de Jesus prefere a oxigenada Glória de corpo cheio. Ele diz a Macabéa: "Você, Macabéa, é um cabelo na sopa. Não dá vontade de comer. Me desculpe se eu lhe ofendi”*.

Macabéa recorre a uma cartomante (a conselho de Glória), que prevê para ela um futuro promissor, o encontro de um estrangeiro rico que vai amá-la; ao deixar a cartomante, 
vê um Mercedes vindo em sua direção e compreende que as previsões começam a acontecer, o moço loiro dirigindo o carro veio buscá-la. Mas o carro não pára e Macabéa é atropelada.

$\mathrm{O}$ destino de Pomme parece menos trágico: deixa o pequeno apartamento do estudante parisiense e volta para a casa da mãe. Perde o apetite e o brilho das bochechas lisas como a casca de uma maçã, detalhe de seu corpo que explica seu apelido; adoece gravemente e um dia cai também no meio da rua. Um carro é obrigado a parar para não atropelá-la. Pomme é internada em uma clínica psiquiátrica, onde recebe, mais tarde, a visita de Aimery. Ele reconhece ainda seu olhar de rendeira, bordadeira ou carregadora de água.

Voltando a essas imagens que aproximam o romance da pintura, podemos dizer que Vermeer imprimiu, em alguns de seus quadros, já no século XVII, um certo olhar sobre as mulheres e as crianças, apresentando-nos a criada, a tecelã, a bordadeira, a rendeira ou a burguesa que escreve cartas em sua casa, sempre na concentração de uma tarefa ou no intervalo dos afazeres domésticos. Nesses momentos, o pintor revela, por meio de seu trabalho, a mulher na plenitude do espírito, mas ainda assim estreitamente ligada à sua realidade imediata e à sua experiência com o corpo. Enfim, o direito à metafísica? Uma metafísica dos simples, dos pobres de espírito.

Essa metafísica também é encontrada em muitos artistas masculinos. Por que Manuel Bandeira, um dos maiores poetas brasileiros, se auto-refere como um poeta menor? Por que muitos consideram Mário Quintana um poeta infantilizado? E como se lê a poesia rasteira, no bom sentido, de um Manoel de Barros? Não haveria, na cultura ocidental, um menosprezo pelo singelo, por aquele que prefere o menos, o simples, o quase nada, o mundo físico, o chão, o pouco, quando desligados do mundo cristão? Talvez por se supor que para problematizar a condição humana na literatura, a dor e o pessimismo sejam armas mais eficazes e menos ingênuas. A busca de um estado de alma mais apaziguado, no entanto, pode passar pelo encantamento com o que há de mais ínfimo e de mais banal, como a vivência de certos instantes do cotidiano de forma metafísica.

Esse tipo de poesia - escrita também com o corpo - tem sido menos estudado ou valorizado pela crítica literária. Não 
"Waldman, Berta. "Prefá cio". Em: Barros, Manoel de. Gramática expositiva do chão (Poesia quase toda). Rio de Janeiro: Civilização Brasilei ra, 1990: 20.)
"Barros, Manoel de. "Sabiá com trevas". Em: A Gramát ca expositiva do chão (Poe sia quase toda). Ob. cit.: 212.) é essa, contudo, a atitude de Berta Waldman ao analisar a obra do poeta Manoel de Barros. A ensaísta nos dá algumas páginas de uma crítica quase poética, em que aproxima a obra do poeta da obra de Clarice Lispector. Ambos fazem parte da família de escritores que têm como preocupação maior a pesquisa da própria alma e do próprio corpo. Assim se refere Berta Waldman a essa forma de trabalhar:

Este tipo de poesia que busca aprofundar e dizer o sentimento singular, aludir ao que não tem sinônimo, mas é index sui, luta para se escrever sem a herança de regras. Como isso é impossível em termos absolutos, o poeta vai sempre testando a sua própria condição de possibilidade expressiva, incorporando as conquistas advindas da tradição e também das vanguardas, capazes de o auxiliar na difícil tarefa.*

Clarice Lispector também dá a impressão de ir criando as regras enquanto escreve, numa pesquisa permanente de si mesma, que é intuitiva, inconsciente, corpórea e também, em muitos textos, controlada pelo intelecto.

Essa possível ruptura com as regras, que Irma Garcia detecta mais presente em textos de mulheres, não seria essa vontade de partir de si mesmo, da experiência de ter um corpo existindo sem que a tradição literária interviesse em primeiro lugar? É certo que muitas mulheres escritoras estiveram fora dessa tradição e quiseram desdenhá-la, privilegiando a intuição. É preciso, no entanto, ver o fenômeno como algo mais amplo, presente também na obra de escritores. Basta ler com atenção alguns versos do próprio Manoel de Barros:

Para entender nós temos dois caminhos: o da sensibilidade que é o entendimento do corpo; e o da inteligência que é o entendimento do espírito.

Eu escrevo com o corpo

Poesia não é para compreender, mas para incorporar

Entender é parede; procure ser uma árvore."

Nos textos de Clarice e também de outros escritores, encontramos muitos personagens que experimentam o entendimento pelo corpo, como é o caso de Macabéa.

Ainda no século XIX, Gustave Flaubert apresenta uma certa Félicité no conto Un cour simple: a doméstica "perfeita” de uma casa burguesa do século XIX. Simplória, ignorante, econômica, mas capaz de uma devoção amorosa devastadora, dedica toda a sua afetividade às crianças da família, de- 
pois a um sobrinho marinheiro que morre embarcado em um país distante e, finalmente, a um papagaio.

A opção por "esses pobres-de-espírito" não é sem razão. Haveria nelas um modo de ver o mundo ainda não fragmentado, uma certa inteireza em apreender o real. Não por acaso Clarice prefere selecionar seus personagens entre crianças, donas de casa jovens ou velhas, bichos (um búfalo, uma barata, uma galinha) ou um ovo.

É José Américo Pessanha quem afirma a respeito de muitos personagens clariceanos:

E eis que chegam os pobres-de-espírito, as crianças, os 'primitivos', os bichos [...] Crianças povoam a obra de Clarice Lispector, em convite à desracionalização: caminho de retorno à realidade viva autêntica do homem. Em convite ao "eu profundo". Por não terem penetrado na idade da razão, não têm ainda adestrados os instrumentos racionais de defesa. E são muito mais espontaneidade e quase só estesia: olhos espantados a olhar o mundo-aí. Descobrindo, compreendendo, 'descortinando' $[\ldots]^{*}$

'(Pessanha, José Américo. "Itinerário da paixão". Cadernos Brasileiros, n. 29. Rio de Janeiro, maio/jun. 1965: 67.)

Ainda segundo Pessanha, a razão discursiva, da qual estão privadas Macabéa e Pomme,

distancia o dado presente e, situando-o logo num tecido de relações, amortece-lhe o impacto e cria um estado psicológico de neutralidade e indiferença. Indiferença das generalizações - nas quais objetos e acontecimentos resultam apenas em casos particulares de uma lei geral, em unidades indiferenciadas de um conjunto homogêneo. Neutralidade que decorre do destacamento intelectual - artifício indispensável à sobrevivência, que dilacera a unidade primitiva do homem, embora o conduza à teorização."

Assim como as crianças e os bichos, Macabéa e Pomme são mais aderentes à realidade imediata. Para elas, como para a realidade primitiva, o encontro com cada coisa requer concentração.

Em muitos dos seus textos, Clarice trabalha com a fruição exaltada do presente. Essa fruição culmina em Água viva, em que a narradora raciocina por intermédio do corpo. Mas muitos de seus personagens, em outros textos, contam apenas com os sentidos, à espera da revelação de uma verdade física, como forma de expressão. São incapazes de formular o que sentem intelectualmente de maneira ordenada.

Não por acaso também Clarice estabelece uma forte relação entre pintura e literatura em Água viva: é como se ela 
"(Nunes, Benedito. "Nota filológica". Em: Lispector, Clarice. A paixão segundo $G$ H. Edição crítica. Florianó polis: EdUFSC, 1988: xxxvi.) precisasse captar o presente ultrapassando os limites da linguagem. A personagem é uma pintora que escreve a alguém e que fala constantemente de pintura, fazendo com que a respiração de um traço ou de uma pincelada estejam concretamente na obra, marcas físicas de um trabalho. A música vibra também por trás de seu texto. Há um cansaço em relação à palavra, essa palavra que nunca a satisfaz.

Mas $A$ hora da estrela retoma a tradição da narrativa, da construção do romance, num momento em que Clarice já havia conhecido o despojamento da linguagem literária. É possível, então, que a estrutura do romance $A$ rendeira tenha sido um suporte inicial para a autora dar forma a Macabéa. Benedito Nunes, em um de seus textos sobre Clarice Lispector, faz a seguinte constatação, dando-nos mais uma razão para relacionar os dois romances:

$\mathrm{Na}$ fase final, trabalhou simultaneamente em $A$ hora da estrela, Um sopro de vida e nos dois contos finais de A bela e a fera. Os fragmentos, que pertenciam a estes três últimos, integraram-se como peças soltas e díspares, igualadas em sua condição de pedaços, a uma só massa quando ela morreu. $\mathrm{O}$ relato $A$ hora da estrela, redigido febril e continuamente do começo ao fim, talvez tenha sido a única exceção ao método do fragmento, segundo o qual foram elaboradas obras tão diversas e tão variáveis quanto ao tempo de composição*.

Em $A$ rendeira, Pomme é descrita por alguém que tenta perscrutá-la, tentando adivinhar sua maneira de sentir. Com Clarice, a "pobre-de-espírito" é revelada em sua crueza. O narrador, um intelectual, fica dividido em relação a Macabéa. Ela o perturba porque o obriga a rever-se, a questionar seu papel social. Mas por trás dele temos a própria Clarice, misto de pesquisadora densa da alma humana e "sonsa literária" diante do mundo. Dessa forma, ela encontra um campo comum, uma irmandade com a personagem, tão diferentes e tão próximas ao mesmo tempo.

\section{Clarice Lispector: a narrativa híbrida}

Tanto Hélène Cixous, na França, quanto Annie Leclerc, no Quebec, percebem os instantes de vida experimentados com intensidade e que precisam ser "ditos". Esse conteúdo de vida parecia buscar uma forma. Quando, no fim dos anos 1970, essas escritoras descobrem a literatura de Clarice Lispector, há algo que se encaixa. Então existe essa grande escritora 
que escreve com o corpo: sua respiração está presente na escrita, como quem pinta um quadro. Parece não haver generalização ou teorização anteriores ao texto. Um ser "inteiro” está tentando expressar sua apreensão de mundo, suas experiências cotidianas de forma lenta, crua, despreparada. Um viver que experimenta se contar com a cara desnuda*.

Para Hélène Cixous, haveria duas formas literárias distintas no que diz respeito à prosa narrativa: a primeira, mais bem acabada, com uma estrutura mais aparente e, em geral, apresentando uma história. A segunda teria um contorno menos definido, como se não houvesse um objetivo a alcançar e como se o texto fosse sendo revelado até mesmo para o próprio escritor.

Ao ser questionada sobre a existência de uma escrita feminina em entrevista ao jornal Folha de S. Paulo, Cixous esclarece: [...] eu não me refiro a uma oposição masculino-feminino, mantenho com aspas. Mas por razões de época mantenho adjetivos como masculino e feminino, mantenho com aspas, quer dizer com precaução, para caracterizar as economias libidinais que podemos fazer surgir, observar e que são diferentes. Vemos essas economias manifestarem modos de ser, quer na vida quotidiana (e é a Psicanálise que dá conta disso) quer nas produções discursivas em geral [...]. Mas se tomarmos por exemplo a questão dos gêneros na literatura, há uma economia libidinal literária que produz o gênero do romance, quer dizer algo de construído, de organizado, de apropriado, delimitado e que obedece a certas regras, tem um começo, um meio, um fim. Eu diria que são caixinhas e que a economia masculina se compraz em enquadrar, reter, ordenar um espaço. Em contrapartida encontramos numa outra economia textos que justamente não são caixinhas, que estariam fora da moldura, enfim não passíveis de serem fechados, sempre em aberto $\mathrm{e}$, contrariamente àquilo que se deixaria enquadrar, estariam num movimento, numa continuidade. Ocorre que são sobretudo as mulheres que deixaram passar esse tipo de texto, são textos simultaneamente jubilatórios e angustiantes, como tudo que recomeça incessantemente.*

Acredita, então, haver mais mulheres criando esse segundo tipo de texto, o que não exclui evidentemente a existência de textos mais bem estruturados de escritoras mulheres nem narrativas menos ordenadas de escritores homens. Talvez Hélène Cixous tenha tentado pensar didaticamente em uma separação entre as formas de escrita, por ter percebido um número maior de mulheres deixando escapar em seus textos
- (Lispector, Clarice. Água viva. Ob. cit.)
"("Entrevista a Betty Milan". vembro de 1982.) 
"(Candido, Antonio. Iniciaçăo à literatura brasileira. 1998, p. 93, grifos nossos)

("Carta de Rubem Braga a Clarice Lispector", Rio de Janeiro, 04 de março de 1957. Arquivo-Museu de Literatura da Fundação Casa de Rui Barbosa.)

"(Lispector, Clarice. A maç no escuro. Rio de Janeiro: Rocco, 1998.) essa espécie de fluidez imprecisa, de que nos fala Antonio Candido em um de seus textos sobre a obra de Clarice Lispector. De qualquer forma, essa separação tem algo de artificial, sobretudo quando se pensa na literatura da escritora brasileira, um caso muito particular que poderia ser considerado híbrido: trata-se de uma autora que também produziu textos mais estruturados, e que, a partir de um determinado momento, aceitou despojar-se do que havia aprendido.

Água viva é o exemplo de texto em que a autora põe em xeque a "construção literária", tentando fazer vibrar sua escrita num casamento entre intelecto, acaso e experiência física.

Em outros momentos, sua obra apresenta textos mais "confortáveis" a muitos leitores no que diz respeito à forma. Críticos literários, como Antonio Candido, chamam a atenção para os contos de Clarice, valorizando-os mais que os romances:

A força desta escritora parece estar na capacidade de manipular os detalhes, que vão se juntando para formar a narrativa e sugerir o mundo, sem que haja necessidade de uma estruturação rigorosa. Daí a fluidez imprecisa que dissolve muitas de suas histórias, ou, pelo contrário, o destaque luminoso que elas ganham na intimidade sugerida pela ampliação do pormenor. Talvez o conto, mais que o romance, seja o instrumento ideal dessa escritora que parece extrair o essencial das dobras do acessório.*

Mas mesmo a leitura dos contos, por revelar o insólito, pode desnortear o leitor. Numa rede narrativa perfeita, enredos e personagens de alguns deles são também perturbadores. Segue abaixo a reação de Rubem Braga à leitura de textos da autora:

Acabo de ler agora os 9 contos que não conhecia: você não imagina como gostei; saio meio crispado da leitura. É engraçado como tendo um jeito tão diferente de sentir as coisas (você pega mil ondas que eu não capto, eu me sinto como rádio vagabundo, de galena, só pegando a estação da esquina e você de radar, televisão, ondas curtas) é engraçado como você me atinge e me enriquece ao mesmo tempo que me faz um certo mal, me faz sentir menos sólido e seguro.*

Em relação aos romances, $A$ maçã no escuro* é considerado pela própria Clarice como o mais bem estruturado - ela o teria reescrito mais de oito vezes. Mesmo assim, a obra ultrapassa o gênero a que se assemelha: não se trata de um romance policial, embora haja uma trama (um crime e uma 
fuga). É o questionamento do personagem Martim e sua espécie de renascimento frustrado na sociedade que vão prender o leitor.

A obra de Clarice Lispector, portanto, apresenta diferentes configurações narrativas, o que nos impediria, a meu ver, de classificar todas as suas formas de expressão dentro de uma escrita feminina, assim como definida por Hélène Cixous. Segundo a ensaísta francesa, haveria uma tendência maior a esse tipo de texto em obras como Água viva ou Um sopro de vida, em que a autora teria realmente aceito sua busca de forma plena, oferecendo-nos textos que se fazem próximos da experiência com o corpo, da concretude do mundo. As reflexões partem sempre daquilo que está sendo vivido. Ela consegue fazer o que parecia impossível para Hélène Cixous: "É algo que está o mais perto possível do corpo, que o mima, quando a literatura em princípio recalca o corpo"**.

"("Entrevista a Betty Milan". Ob. cit.: 74.)

A que Annie Leclerc, Hélène Cixous ou Madeleine Gagnon estavam querendo se referir, ao falar do feminino na literatura presente no livro La venue à l'écriture? Não estariam pensando no engajamento do corpo e do espírito na empreitada da escrita? Um corpo e um espírito que se perscrutaram entre uma tarefa e outra, num fragmento de vida, num momento do dia ou da noite em que a desordem invadiu a ordem e em que várias escritoras (e também alguns escritores) teriam deixado o espírito vir à tona?

Esta questão é feita para tentarmos entender a apropriação que algumas mulheres francesas e canadenses fizeram da obra de Clarice Lispector ao incorporar a autora à causa feminista no fim dos anos 1970. Hélène Cixous a considera uma iniciadora, tendo sido capaz de abrir um território que a francesa sequer imaginava adentrar um dia. Clarice passa a ser uma espécie de líder póstuma de um grupo de mulheres detentoras de um tipo de texto mais comum entre escritoras, de uma escrita feminina que quer se impor no mundo literário.

Esse é o ponto mais delicado: a fluidez imprecisa em Clarice parece o resultado de uma busca individual do seu trabalho com a escrita num momento de sua vida em que as construções conhecidas por ela não a satisfazem mais, em que a suposta beleza da literatura chegou até mesmo a irritá-la. Ao que parece, essa postura não se inseriu num projeto literário organizado, mas antes foi se construindo sobre a inquietação 
"(Lispector, Clarice. A des coberta do mundo. Rio de Janeiro: Rocco, 1999.) que a autora sempre conheceu: um estado de alerta que a impedia de repetir o que havia efetuado e de se satisfazer com o trabalho já feito. Esse procedimento é o de muitos artistas, homens ou mulheres, diante de um trabalho real de descoberta: uma busca constante, descartando o embuste e a acomodação. Na trilha de um caminho próprio, contudo, Clarice parece ter inaugurado uma aventura que diz respeito ao universo feminino.

Trajetória bastante difícil e complexa também para ela, pois, historicamente, não há como negar o lugar ocupado pelas mulheres na sociedade durante séculos: o fato de terem estado ligadas mais ao mundo da casa e à criação dos filhos, a uma certa reclusão, pode tê-las levado a uma formulação própria de sua visão de mundo, e isto então se refletiria em muitos dos textos por elas produzidos. Uma metafísica própria ligada a um tipo de experiência de vida pôde, talvez, surgir. Essa apreensão muito sutil do mundo é uma herança que muitas mulheres acabaram carregando. Há vários fatos históricos, concretos, que mostram como foi difícil para uma escritora se impor num meio literário determinado. Foi também o caso de Clarice Lispector. Sua correspondência com Fernando Sabino mostra o quanto ela precisou da leitura do amigo para finalizar seu quarto romance. As opiniões do escritor determinam a exclusão de um prefácio e do eu-narrador da versão final de $A$ maçã no escuro.

Clarice tinha medo do "julgamento" masculino e vivia pedindo opinião a seus muitos amigos escritores. Ela soube por alguém que Rubem Braga não apreciava suas crônicas publicadas no Jornal do Brasil. Responde ao cronista brasileiro no próprio jornal com uma ponta de mágoa: "Rubem, eu faço o que eu posso [...] Faço crônicas humildemente, Rubem. Não tenho pretensões. Mas recebo cartas de leitores e eles gostam. E gosto de recebê-las"*.

Certamente Clarice também influenciou muitos de seus amigos, como Fernando Sabino, Rubem Braga, Otto Lara Resende, Paulo Mendes Campos e João Cabral de Melo Neto. Mas não temos notícias de cortes ou sugestões tão concretas como aconteceram com ela. E nem justificativas públicas sobre determinado tipo de trabalho. Pelo que se sabe, Clarice teria acatado algumas sugestões, refutado muitas, sabendo manter-se fiel a seu universo. 
Segue, por fim, um trecho da correspondência entre Clarice Lispector e Fernando Sabino, no qual se percebe o quanto o diálogo entre eles foi frutífero para a construção da obra de cada um. E também para vermos como Clarice, já em 1946, pensava em escrever um romance em que uma pobre de espírito seria seu personagem central:

E eis-me aqui, em pé. Por que é que eu acho que você pode tão bem fazer exatamente essa história com título de movimentos simulados? Mas acho muito. Você diz num pedaço: o verdadeiro testemunho é o dos santos e nossa tristeza mais irremediável é de nem ao menos saber onde é que perdemos nossa única oportunidade de sermos santos. Fernando, meu Deus, pois você falou numa coisa que está ligada ao trabalho que eu estava tentando e abandonei:

Tratava-se de uma moça que, porque era curta de espírito e muito lenta, forçava muito esse espírito fraco e isso dava uma espécie de santidade. Meu Deus, nem sei explicar, estou vendo que você não pode entender assim. Mas porque ela era desses fracos, ela forçava o espírito para ver a realidade - "mas era mais fácil ver o sobrenatural do que a realidade". Ela forçava um momento de "santidade" para estar à altura das coisas que ela via com uma clareza intransponivel e estúpida."

" (Lispector, Clarice. "Carta a Fernando Sabino, Berna, 14 de agosto de 1946". Em: Car. tas perto do coração. Rio de Janeiro: Record, 1977: 53,
grifos nossos.) 


\section{Lúcia Peixoto Cherem}

Professora de língua e literatura francesa da Universidade Federal do Paraná. Doutora na área de literatura pela USP, sob orientação da prof $^{a}$ Dra $^{\mathrm{a}}$ Glória Carneiro do Amaral. Publicações: método de ensino de francês: Mon ami Thomas., vols. 1 e 2 (Paris: Hatier, 1988-9), Vestibular UNICAMP - língua estrangeira - francês (com Rosa Maria Nery, São Paulo: Globo, 1993). Tradução para o francês de $A$ mulher que matou os peixes (La femme qui a tué les poissons), de Clarice Lispector (Paris: Seuil, 1997). Tradução de Langues de feu, de Claire Varin, para o português (Limiar, 2001).

Palavras-chave literatura brasileira literatura francesa escrita feminina

Key words

Brazilian literature French literature Feminist writing

Mots-clés littérature brésilienne littérature française écriture feminine
Recebido em 30/09/2003

Aprovado em 05/12/2003

\section{Resumo}

Neste trabalho procuramos comparar duas obras literárias que apresentam estruturas narrativas muito semelhantes: A hora da estrela, de Clarice Lispector e La dentellière, de Pascal Laîné. A aproximação dos dois romances se torna mais interessante se lembrarmos que foi a própria Clarice quem traduziu o texto francês. $\mathrm{O}$ fato não desmerece de maneira alguma o trabalho da escritora brasileira. Ao contrário, sua personagem Macabéa e a construção da narrativa surpreendem como sempre. Além disso, podemos ver como as personagens femininas das duas narrativas se colocam no mundo, tentando, cada uma a seu modo, uma certa transcendência, que chamamos aqui de metafísica do instante.

\section{Abstract}

This article aims at comparing two literary works which present very similar narrative structures: A hora da estrela, by Clarice Lispector, and La dentellière, by Pascal Laîné. The comparison of both novels becomes even more interesting if we keep in mind that Clarice herself translated the French text. This fact does not diminish in any way the work of the Brazilian writer. On the contrary, the character Macabéa and the construction of the narrative are as surprising as usual. Furthermore, we may notice how the feminine characters of both narratives feel about their roles in this world, each one trying in her own way to reach a certain transcendence, which is referred to in this text as a metaphysics of the instant.

\section{Résumé}

Dans ce travail nous essayons de comparer deux oeuvres littéraires qui présentent des structures narratives semblables. Le rapprochement de ces deux romans devient plus intéressant si l'on se souvient que Clarice Lispector est la traductrice du texte français. Ce fait ne diminue pas du tout le travail de l'auteur brésilienne. Au contraire, son personnage Macabéa et la construction du récit surprennent comme d'habitude. En outre, nous pouvons voir comment les personnages féminins des deux récits se placent dans le monde, tout en essayant, chacun à sa manière, d'atteindre une certaine transcendance que l'on appelle ici métaphysique de l'instant. 